\title{
Gradual changes of houses after the reconstruction program - a case study in Yogyakarta after the 2006 Yogya earthquake
}

\author{
Hiroshi Imai ${ }^{1, *}$, Teddy Boen ${ }^{2}$ \\ ${ }^{1}$ Architect, Senior Researcher, Mohri, Architect \& Associates, Inc., Advantac Nihonbashi Building 3-2-13, Nihonbashi- Honcho, Chuo \\ ku, Tokyo, 103-0023, Japan \\ ${ }^{2}$ Senior Advisor WSSI (World Seismic Safety Initiative)
}

\begin{abstract}
Since 2006, a survey about the reconstruction of houses after the May 2006 Yogya earthquake has been conducted related to the quality of construction and additional works. The gradual changes after the reconstruction program was terminated, were based on owner's preferences and capabilities. After the 2009 West Sumatra earthquake, many damaged houses and schools were retrofitted using ferrocement layers. The purpose of this study is to investigate the possibility to disseminate the same retrofitting method for existing houses in Yogya.
\end{abstract}

\section{Introduction}

On $27^{\text {th }}$ May 2006, an M 6.3 struck Yogyakarta Province. Many houses were heavily damaged and collapsed [1].

During the reconstruction period, the government provided grants for 3 main activities:

a. Grant-in-aid program for the reconstruction of houses: the fund for the housing reconstruction grant system was IDR15,000,000 (approx. US\$1,500) for heavily damaged, IDR 4,000,000 (approx. US\$400) for moderately damaged, IDR1,000,000 (approx. US100\$) for houses with minor damage

b. To develop key requirements for safer construction

c. Develop and introduce a building certification application system

The Government required a standard construction to be used as a model during the reconstruction. The area of the model house was $36-\mathrm{m}^{2}(6 \mathrm{~m} \mathrm{x} 6 \mathrm{~m}$ plan) and used R.C. practical columns and beams as confinement of the walls. The reconstruction program for housing in Yogyakarta was funded through a grant with the following activities: designing, certification, and construction. These reconstruction programs were implemented as participatory and community-based; and was reported as a successful case for reconstruction in developing countries [2]. The housing reconstruction recovery program was completed in December 2007. For the key requirements, existing guidelines was used [3, 4], and for the certification, a Building Permit System was developed by JICA in cooperation with Gajah Mada University.

For this case study, the survey was conducted in Trimulyo village of Bantul, Jetis, shown in Table 1. In these areas, the ratio of collapsed houses was over $60 \%$ of 4,277 existing houses before the earthquake. 300 houses were selected for the survey as samples.
Table 1. Survey target area and numbers

\begin{tabular}{|c|c|c|c|c|c|}
\hline \multirow[b]{2}{*}{ District } & \multirow[b]{2}{*}{$\begin{array}{c}\text { Sub- } \\
\text { District }\end{array}$} & \multirow[b]{2}{*}{ Village } & \multirow[b]{2}{*}{ Sub-Village } & \multicolumn{2}{|c|}{ Number of house } \\
\hline & & & & \begin{tabular}{|c|} 
Before \\
Eq
\end{tabular} & $\begin{array}{c}\text { Survey- } \\
\text { ed }\end{array}$ \\
\hline \multirow{13}{*}{$\begin{array}{l}\text { E } \\
\text { 䔍 } \\
\text { ص }\end{array}$} & \multirow{13}{*}{$\stackrel{\mathscr{0}}{\stackrel{0}{\varrho}}$} & \multirow{13}{*}{$\stackrel{\supseteqq}{\stackrel{\Xi}{\Xi}}$} & 1. Bembem & 320 & 25 \\
\hline & & & 2. Blawang 1 & 380 & 25 \\
\hline & & & 3. Blawang 2 & 410 & 23 \\
\hline & & & 4. Bulu & 416 & 26 \\
\hline & & & 5. Cembing & 310 & 24 \\
\hline & & & 6. Denokan & 250 & 22 \\
\hline & & & 7. Karangsemut & 205 & 23 \\
\hline & & & $\begin{array}{ll}\text { 8. } & \text { Kembang } \\
\text { Songo }\end{array}$ & 585 & 24 \\
\hline & & & 9. Ponggok 1 & 340 & 25 \\
\hline & & & 10. Ponggok 2 & 475 & 30 \\
\hline & & & 11. Puton & 360 & 23 \\
\hline & & & 12. Sindet & 226 & 30 \\
\hline & & & Total number & 4277 & 300 \\
\hline
\end{tabular}

\section{Condition of reconstructed houses in Yogyakarta, 2007, 2013}

\subsection{Reconstructed houses considered as core houses.}

Core houses are frequently introduced but seldom really understood. Information spread was that the $36 \mathrm{~m}^{2}$ house should be considered as a core house that could be extended by the beneficiaries at a later date. Such understanding became very common in Indonesia, while in fact, in earthquake-prone countries like Indonesia, it is

\footnotetext{
Corresponding author: imai@mohri-aa.co.jp
} 
not advisable to encourage beneficiaries to extend their houses unless the extension is pre-designed and all the connections for the extension are already in place.

The extension and the original core house must be connected structurally to act as one integral unit when shaken by earthquakes. Subsequently, the newly constructed house must be re-analyzed because it will behave differently than the original house. Or the extension part shall be structurally completely separated from the core house. From the evidence on site, those extended houses were built without taking into account any of the above-mentioned requirements and it seemed that until today, nobody takes notice because of the lack of understanding with regard to the seismic problems of core houses.

As mentioned above, the standard size of the floor was $36 \mathrm{~m}^{2}$. Fig. 1. and Fig. 2. show the changing floor area by extension work in 2007, 2009, and 2013. Seven years after reconstruction, floor area becomes around 60 $\mathrm{m}^{2} .65 .3 \%$ of owners extended the original houses. The average extension area of houses is $17.87 \mathrm{~m}^{2}$. It is evident that one family needs a minimum floor area of $60 \mathrm{~m}^{2}$.

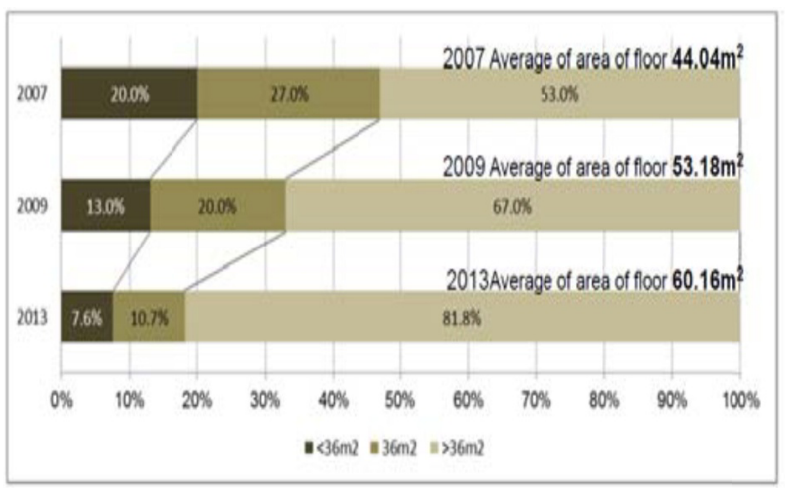

Fig. 1. Area of the floor of reconstruction houses

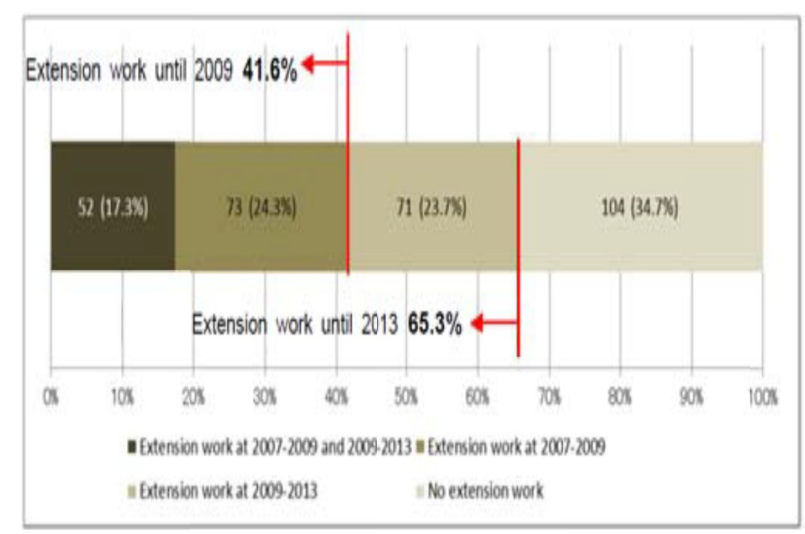

Fig. 2. Period and percentages of extension work

\subsection{Quality of the reconstructed houses in $\mathbf{2 0 0 7}$}

A survey was conducted to check whether the quality of construction followed the "Key Requirements", namely:

a. Area of the wall of confined by RC columns and beams - Key Requirement (KR): It should be smaller than $9 \mathrm{~m}^{2}$. b. Size of RC columns - KR: $150 \mathrm{~mm} \times 150-\mathrm{mm}$, main reinforcement bar should be $4 \times 10 \mathrm{~mm}$ diameter with stirrups $\varnothing 8-150 \mathrm{~mm}$.

c. Size of RC beams - KR: $150 \mathrm{~mm}$ in height and 120 $\mathrm{mm}$ in width, main reinforcement bar should be $4 \mathrm{x}$ $10 \mathrm{~mm}$ diameter with stirrups $\varnothing 8-150 \mathrm{~mm}$

d. Laying brickwork - neat and uniform mortar filling

e. Quality of concrete - good quality materials, good gradation, and sufficient mortar

Fig. 3. shows the quality of construction of new houses.

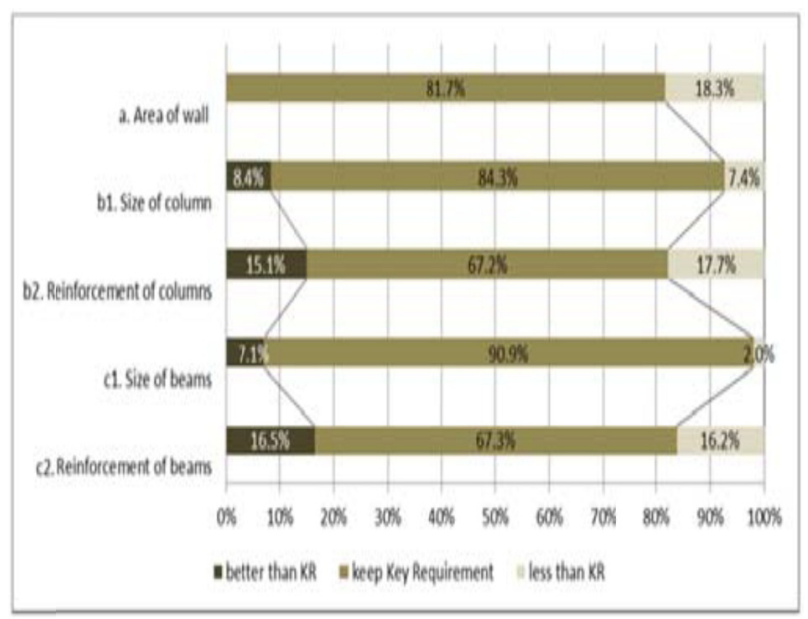

(A) Material and design items

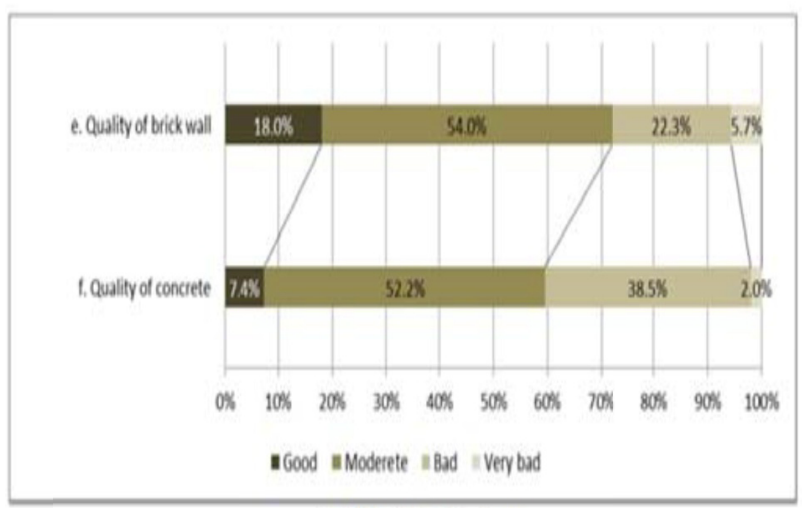

(B) Workmanship items

Fig. 3. Quality of reconstruction houses in 2007

The results of the surveys indicated the following information:

a. The quality of construction materials such as reinforcing bar was good compared to construction key requirements. Most probably the materials were purchased by community units and distributed during the reconstruction.

b. Concrete quality and detailing of reinforcing bars were not in accordance with the key requirements. In Yogyakarta, same as in most areas of Indonesia, construction works were done by individual masons. Besides that, there was insufficient equipment such as concrete mixers, vibrators, and a lack of knowledge of proper construction. 
During the reconstruction phase, the government employed supervisors, called "facilitators" for the reconstruction of houses. However, these facilitators were new university or college graduates that did not have experience of actual construction works. Therefore, most of the supervision for the construction work was not effective. The survey indicated that it is necessary that non-engineered constructions be introduced in the earthquake engineering syllabus and the subject on building construction must be refreshed. Equally important is to introduce non-engineered construction in the curriculum of technical high schools and also to raise the competence of local tradesmen.

\subsection{Comparison quality of construction during reconstruction and afterwards}

Fig. 4. shows the existence of R.C. gable beam as an indication of observing the key requirements.

During the reconstruction, more than $80 \%$ of the houses followed key requirements, however, for the extension parts, only less than $50 \%$ were constructed by using R.C. beams for the brick gable walls. House owners and local masons do not know about earthquake resistant features that must be followed based on the key requirements. This is caused by the fact that during the reconstruction, the facilitators were not qualified and thus did not explain in detail about the need to follow the key requirements.

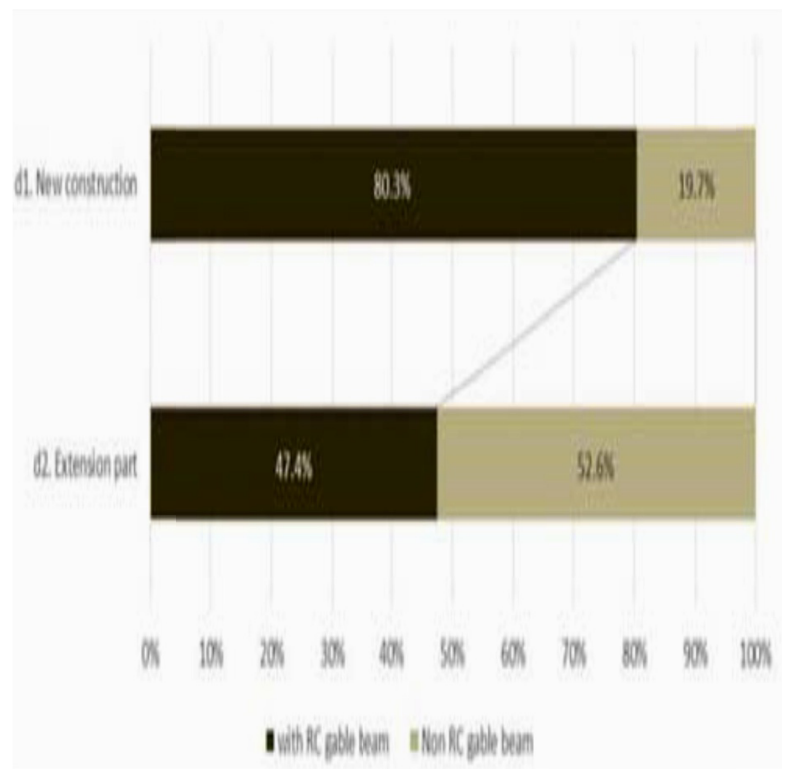

Fig. 4. Existence of R.C. gable beam

\subsection{Finishing works of reconstructed houses (plastering and painted)}

Based on surveys and observations, the process of construction was as follows:

Step 1: foundation, the wall as structure part and roof were constructed with the government grant-aid, to provide shelter and decent living environment such as avoiding rain, wind, sunlight, the insect as basic human needs.

Step 2: finishing of interior and extension work were done funded by homeowners to raise the quality of living environment.

Step 3: after the above two steps, owners did exterior finishing works.

Fig. 5. and Fig. 6. show the existence of exterior finishing works in 2009 and 2013. During the reconstruction, very few houses were constructed up to finishing such as plastering or painting.

About two years after the reconstruction (2009), 30\% of houses started finishing works, subsequently, up to 2013 , almost $60 \%$ of the houses did exterior finishing works.

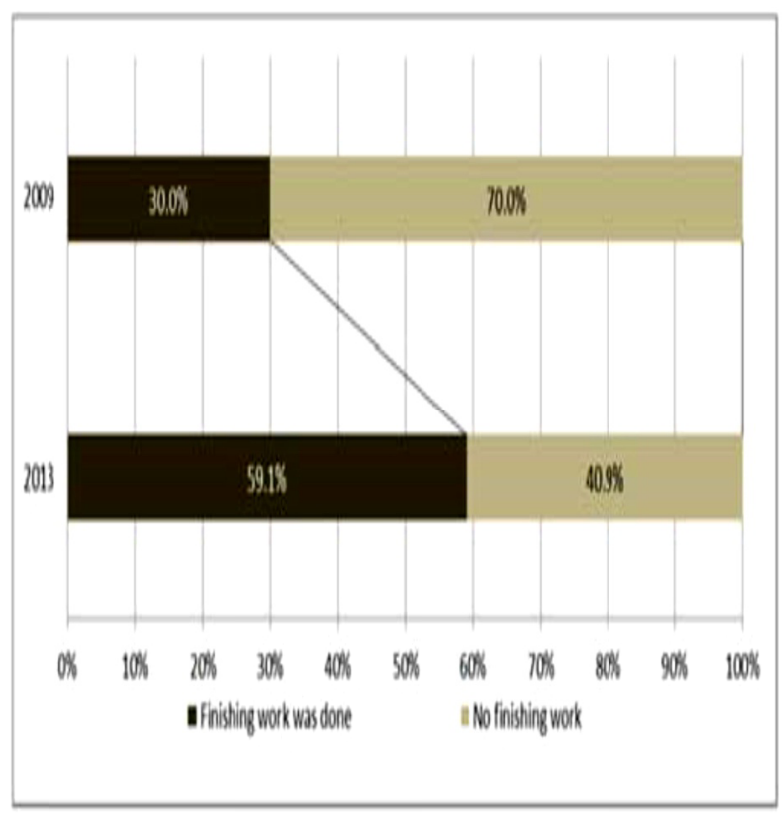

Fig. 5. Existence of finishing works (plastering or painting)

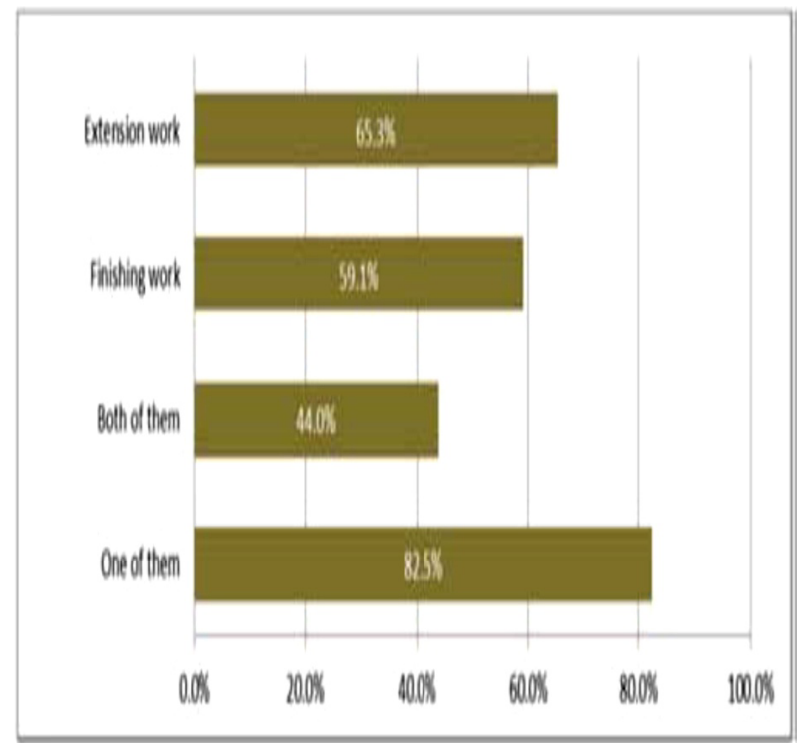

Fig. 6. Existence of finishing works, and extension works 


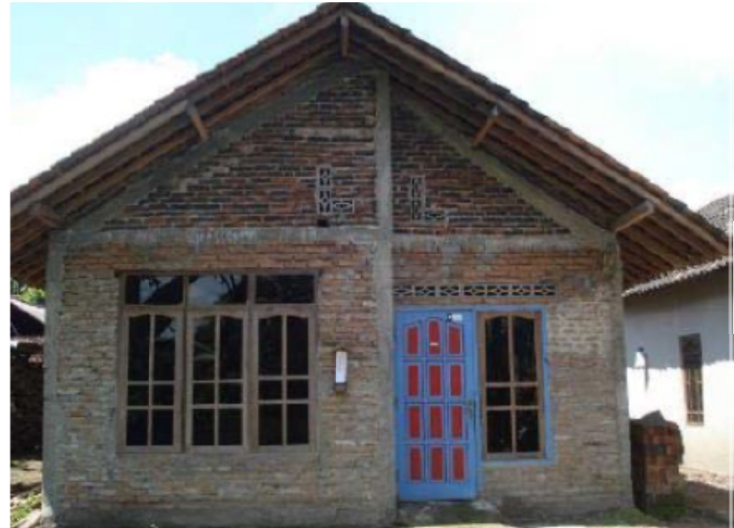

2009 -Original reconstructed house.

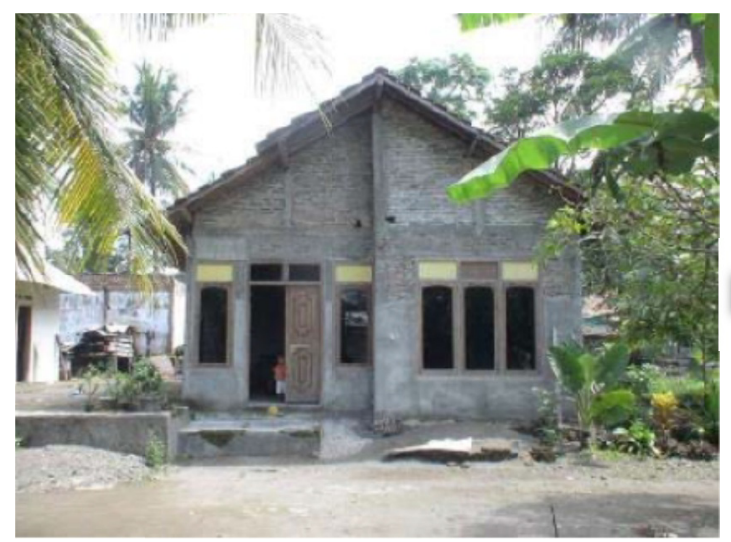

2009 - Original house already with exterior plastering
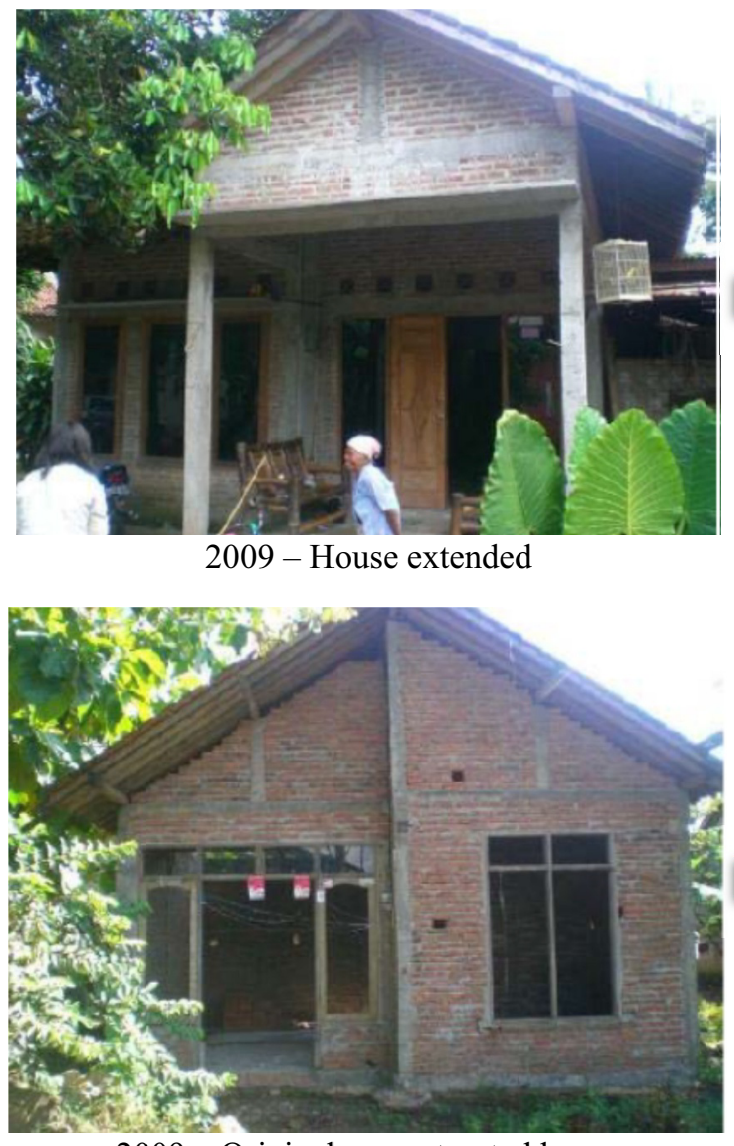

2009 - Original reconstructed house

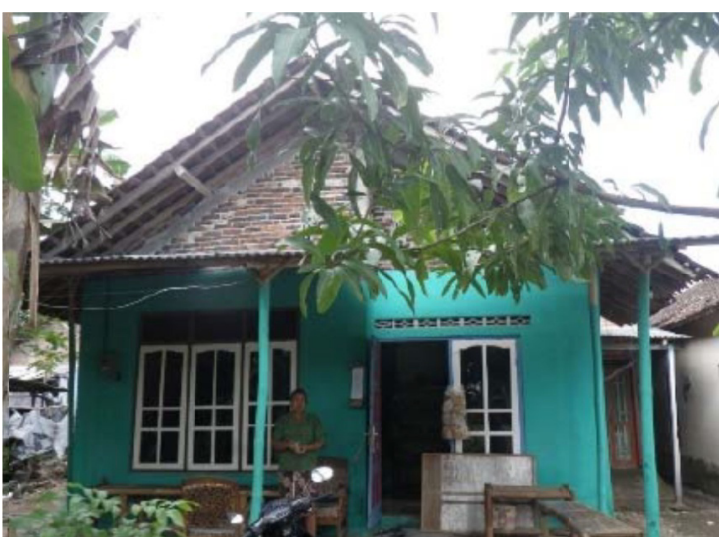

2013 - Original house with exterior plastering and painting

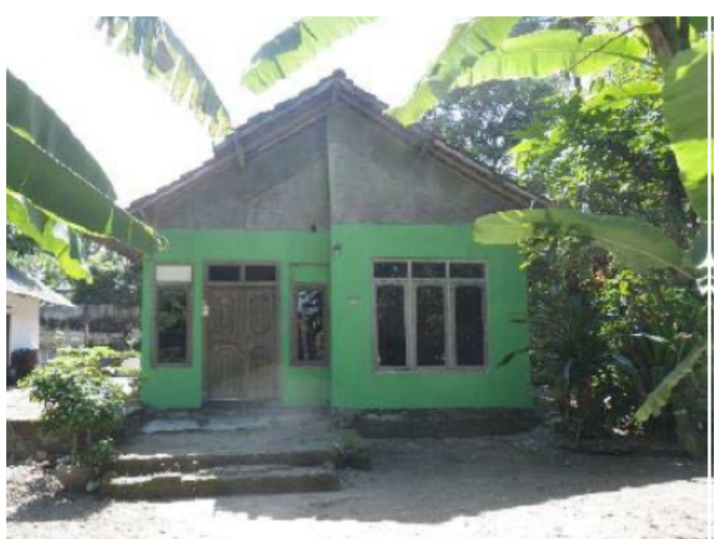

2013 - Original house painted

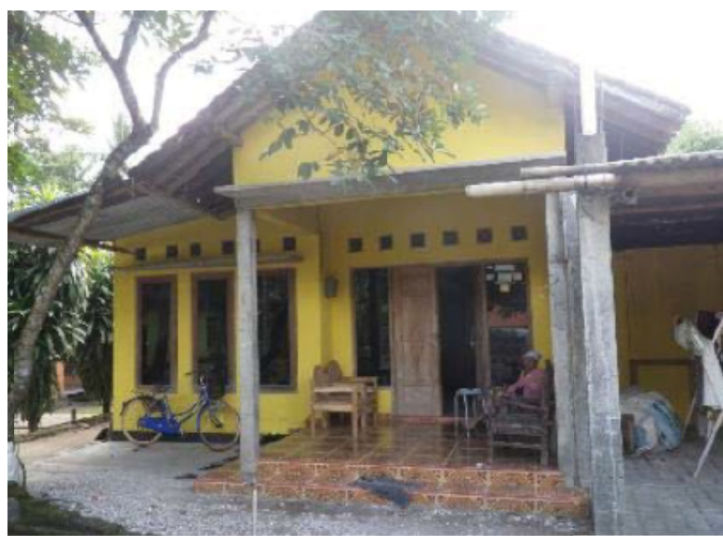

2013 - House with exterior plastering and painting

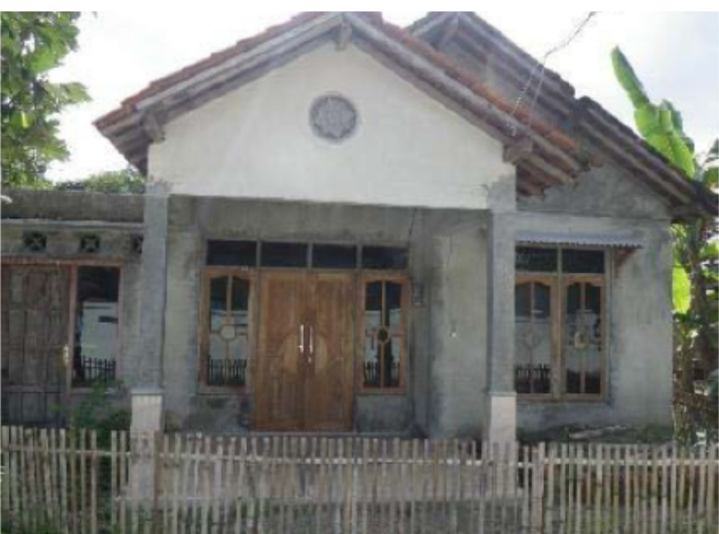

2013 -House extended and exterior plastering

Fig. 7. Picture showing gradual changes of the reconstructed houses 


\subsection{Cost estimation}

As shown in Table 2. since 2009 to 2013, more than $80 \%$ of the reconstructed houses conducted finishing works and some added extensions to the original house at the owner's expense. In other words, residents spent own funds for upgrading their living environment. However, the extension of the houses did not take into account earthquake resistance features based on the key requirements.

Table 2. Estimation Of Additional Work (Rate Us $\$ 1=\mathrm{Idr}$ $11,000-2014)$

\begin{tabular}{|c|c|c|c|c|}
\hline & $\begin{array}{c}\text { Cost } / \mathbf{~ m}^{\mathbf{2}} \\
(\text { IDR) }\end{array}$ & $\begin{array}{c}\text { Average } \\
\text { area }\left(\mathbf{m}^{\mathbf{2}}\right)\end{array}$ & $\begin{array}{c}\text { Total cost } \\
\text { (IDR) }\end{array}$ & $\begin{array}{c}\text { Total cost } \\
\text { (US\$) }\end{array}$ \\
\hline $\begin{array}{c}\text { Extension } \\
\text { work }\end{array}$ & 830,000 & $17 .{ }^{*}{ }^{*}$ & $14,857,000$ & 1,350 \\
\hline $\begin{array}{c}\text { Finishing } \\
\text { work }\end{array}$ & $28,720{ }^{* 1}$ & $72.0{ }^{* 2}$ & $2,067,840$ & 188 \\
\hline \multicolumn{4}{|c|}{ from the survey in $2009 ;{ }^{* 2}$ from the survey in 2013} \\
\hline
\end{tabular}

\subsection{Conclusion}

The gradual changes of the original house indicate the preferences and needs of the owners. The original floor area of the houses stipulated by the government was 36 $\mathrm{m}^{2}$, however, the actual need is $60 \mathrm{~m}^{2}$. The survey results indicated that the quality of the original house and the extension were different and unfortunately, the extensions did not follow the key requirements.

The existence of R.C. practical columns and beams is one of the critical points, the percentage of the existence of R.C. confinement was reduced from $80 \%$ to $50 \%$. On the other hand, owners spend money for living environment and construct a different facade of the house. Almost $60 \%$ of houses applied to finish work 6 years after construction. Fig. 7. shows an example of the gradual changes of the original houses.

Based on the findings, it is strongly suggested to retrofit all houses built after the reconstruction by a simple, affordable and suitable method, namely using wire mesh as ferrocement layers.

\section{A Case study of retrofitting in Padang, 2012}

\subsection{Outline of retrofitting work}

To introduce and disseminate retrofitting of existing houses in Indonesia, JICA conducted a practical, on-thejob training in Padang-Pariaman and Nias. Local masons were trained on the job regarding how to retrofit masonry houses using wire mesh as ferrocement layers.

The existing houses were retrofitted by on the job training of 50 local masons. At the same time, local masons were trained to build houses based on the key requirements.

\subsection{Retrofitting method}

The method of retrofitting using wire mesh covered by mortar is described and shown in Fig. 8 should be applied $[5,6]$.

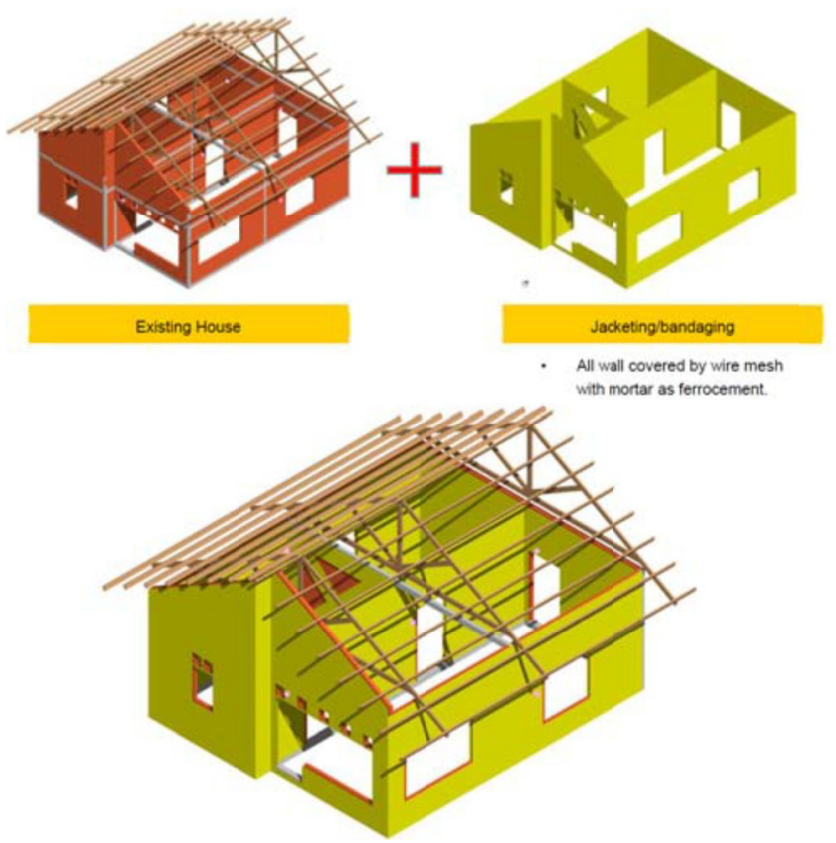

Image of retrofitting method for existing building
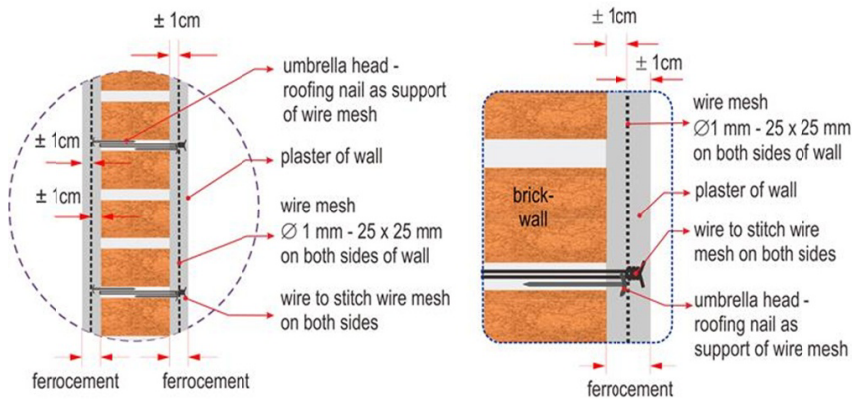

Detail of reinforcement using wire mesh

Fig. 8. Retrofitting method (wire mesh full jacketing)

\subsection{Condition of existing house}

This retrofitted house was built in 1991 and was shaken by the 2007, 2009 earthquakes. There was no visible damage. However improper construction was detected. The houses were made of confined masonry with halfbrick-thick walls as non-engineered construction. The Condition of the model house, as follows:

a. The building was standing on soft soil. However, the plinth beam was strong enough, because there was no damage on the plinth after being shaken by two large earthquakes.

b. The gable wall should be strengthened.

c. The walls and confinement elements should have good connections, such as between brick walls and columns and beams, between intersecting walls and between walls and foundations. 


\subsection{Materials and equipment}

1) Wire mesh: Galvanized welded wire mesh, spacing $25 \mathrm{~mm}$, diameter $1 \mathrm{~mm}$ purchased in the local market in Padang-Pariaman. (Fig. 9.)

2) Fixing tools and materials: electric drill for making a hole on the existing wall, Bending wire, Nail for temporary fixing. (Fig. 9.)

3) For Plastering: The ratio of cement and sand was $1 /$ 4 by volume and the water-cement ratio was 70\%.(Fig. 9.)

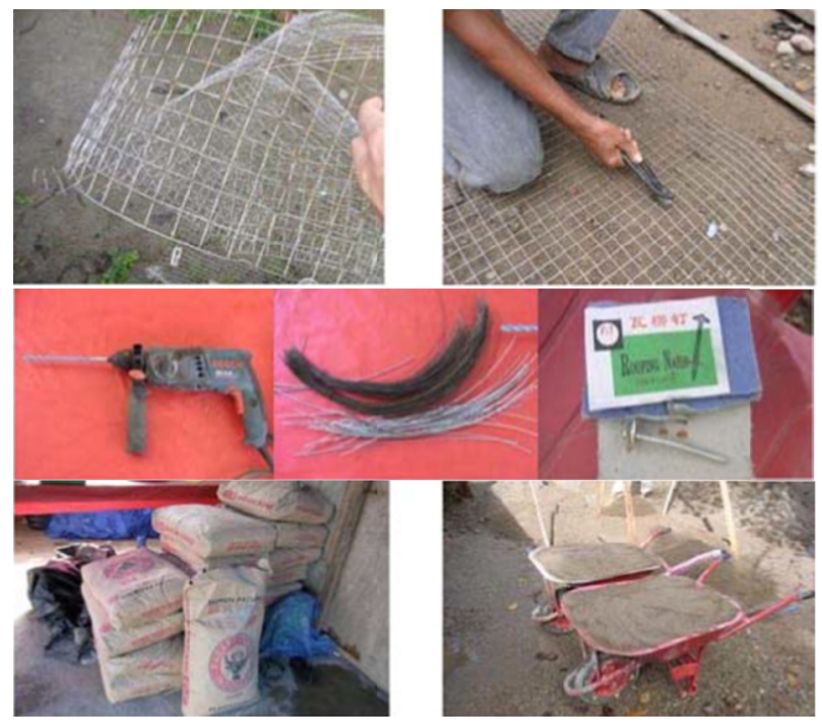

Fig. 9. Materials and equipment

\subsection{Procedure of retrofitting construction}

1) Preparation of wire mesh: Cutting size and bending for corners, it was better to prepare before assembling for corner and top of walls. (Fig. 10. Fig. 14.)

2) Setting umbrella-head-roofing-nails as support of wire mesh and keeping $1 \mathrm{~cm}$ distance from a brick surface with approx. $20 \mathrm{~cm}$ spacing. (Fig. 10. - Fig. 14.)

3) Make holes by drilling the masonry wall at the joint mortar, with the spacing of approx. $40 \mathrm{~cm}$. (Fig. 10.Fig. 14.)

4) Inside and outside wire mesh was stitched by using tie wire inserted through holes in the wall. (Fig. 10.Fig. 14.)

5) Wire mesh should be installed from bottom to top of the wall. (Fig. 10. - Fig. 14.)

6) The top of the wall also should be covered by wire mesh. (Fig. 10. - Fig. 14.)

7) Tying inner and outer wall wire mesh layers are very important using four bending wires. (Fig. 10. - Fig. 14.)

8) The Connecting hole should be filled up by grouting cement water. (Fig. 10. - Fig. 14.)

9) The ratio of cement and sand was $1 / 4$ by volume was used. (Fig. 10. - Fig. 14.)

10) The Thickness of plastering on wire mesh required minimum $2 \mathrm{~cm}$. (Fig. 10. - Fig. 14.)

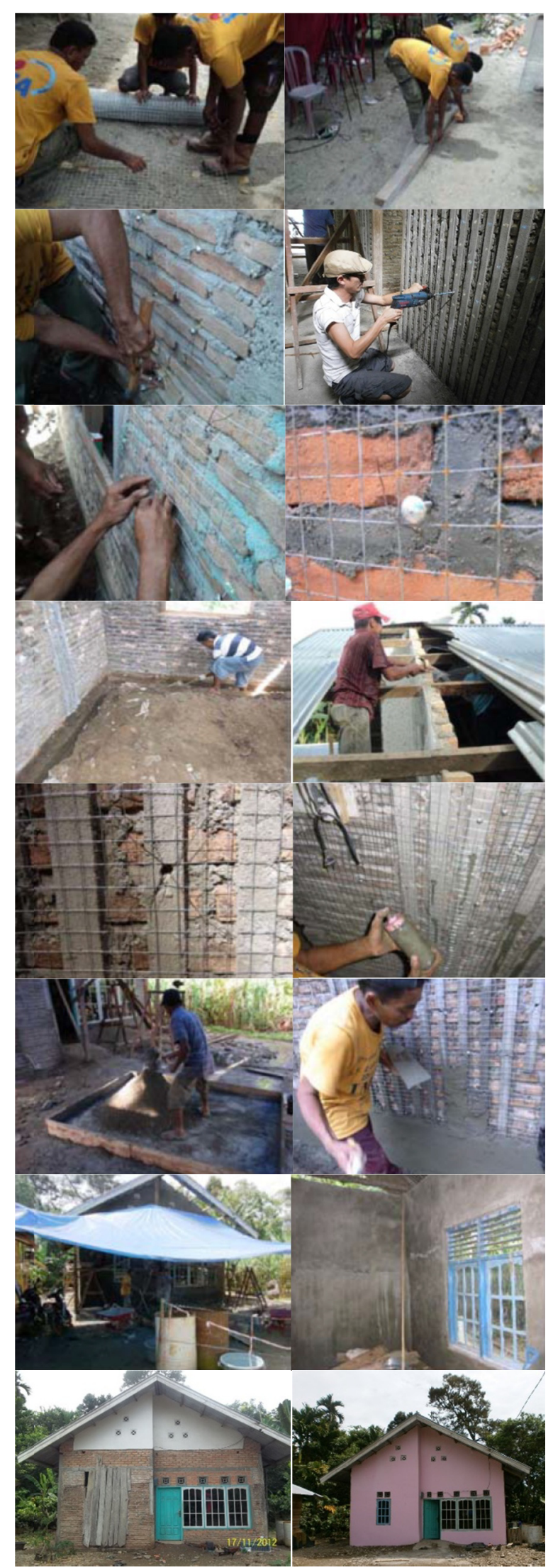

Fig. 10. Retrofitting work at Tanjung Basung - Padang Pariaman 


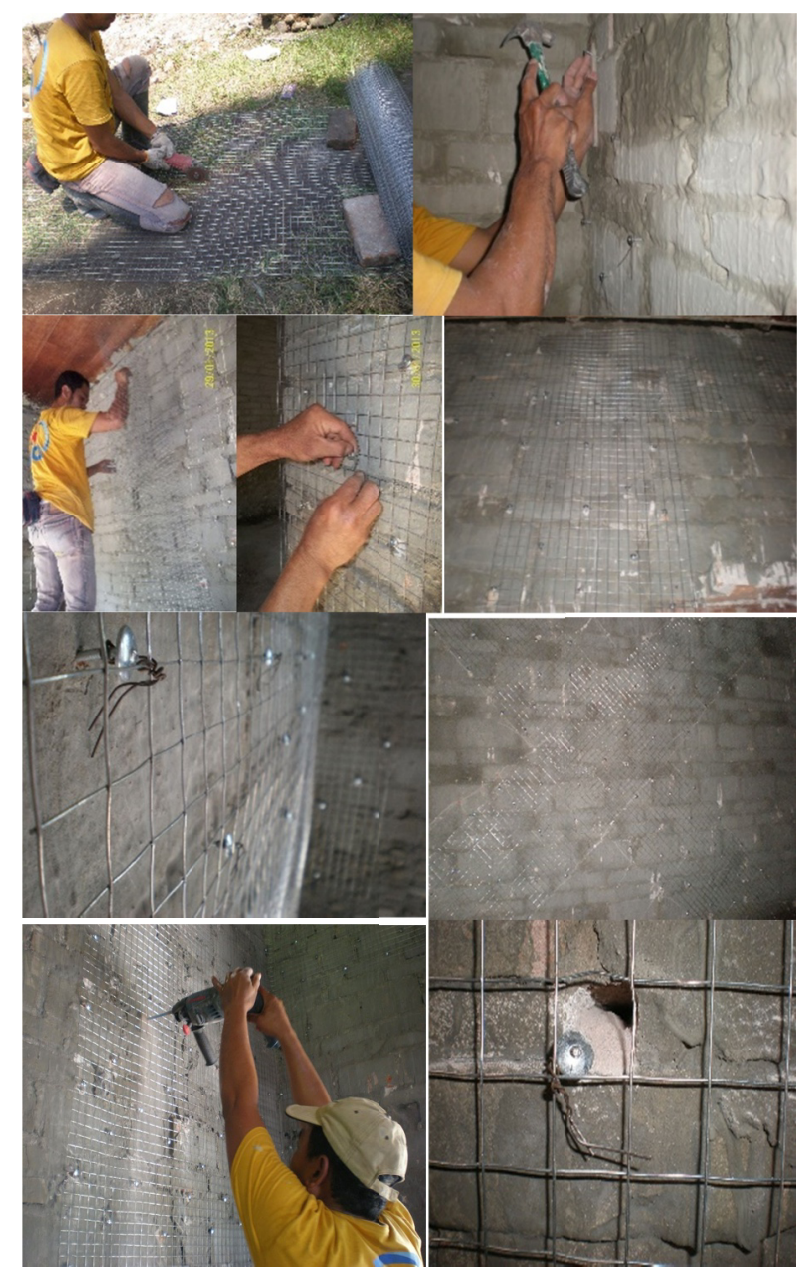

Fig. 11. Retrofitting work at Gadur - Padang Pariaman

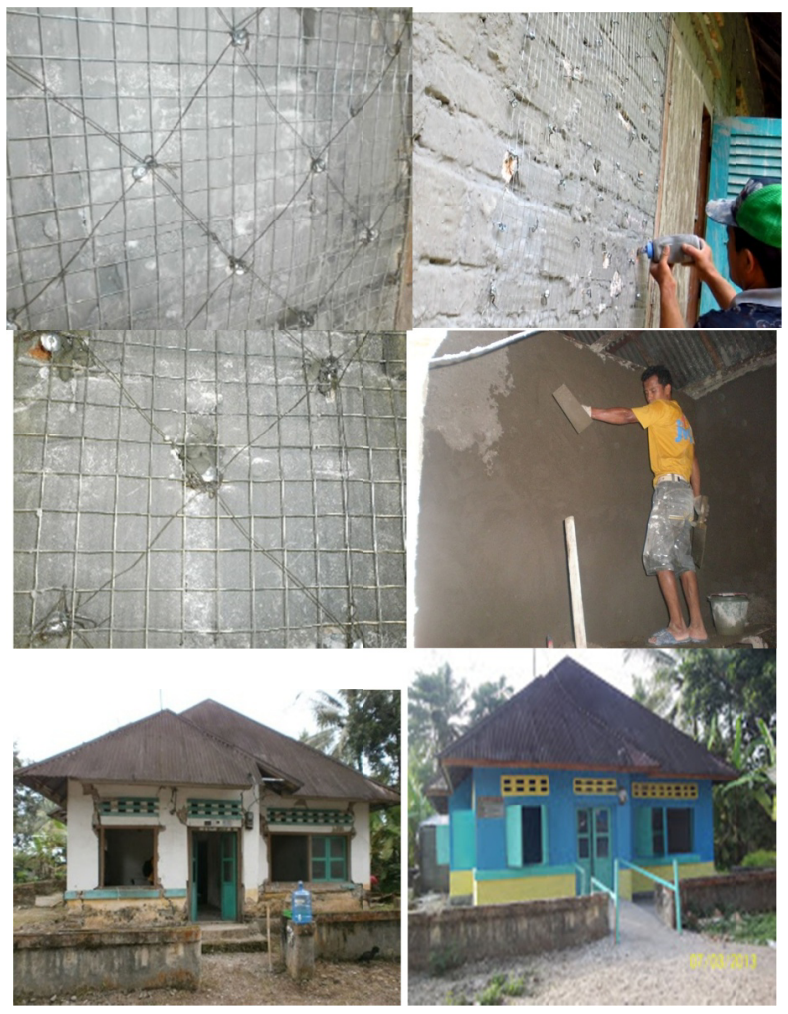

Fig. 11. Retrofitting work at Gadur - Padang Pariaman(cont'd)

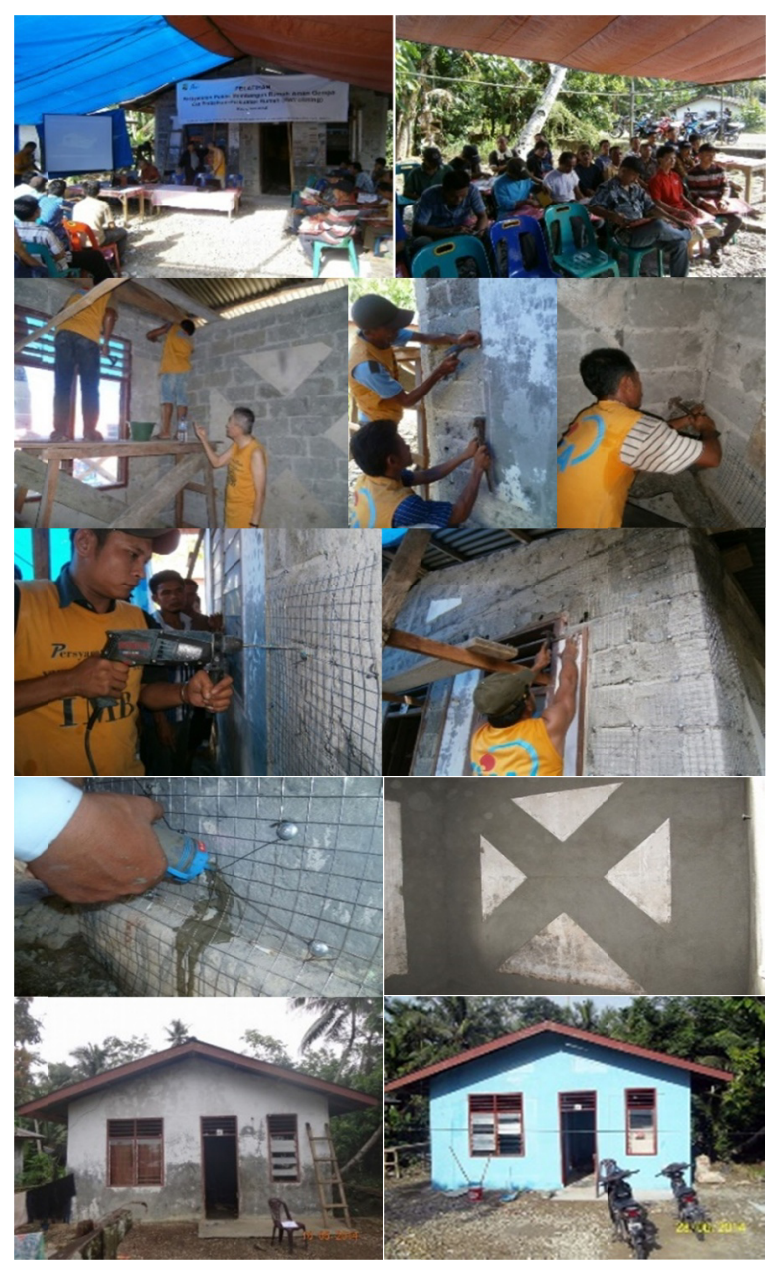

Fig. 13. Retrofitting work at La'uri,Village, district of Sogaeadu, Nias Regency

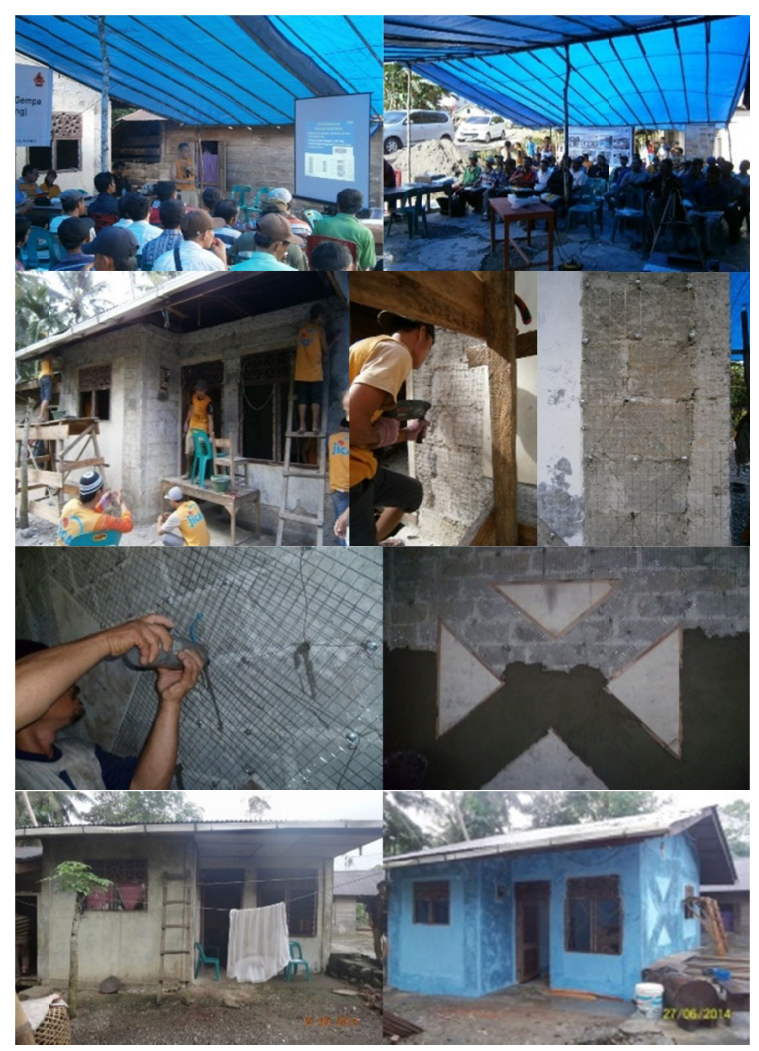

Fig. 14. Retrofitting work at Kab. Nias Barat 


\subsection{Cost estimation of retrofitting work in December 2012 for West Sumatra.}

Table 3. shows the approximate retrofitting cost of the house at Tanjung Basung - Padang Pariaman.

The market price of new construction in 2012 is approximately IDR $1,500,000 / \mathrm{m}^{2}$. The cost to build a new house with $59.185 \mathrm{~m}^{2}$ footprint similar to the house in those areas is approximately IDR 89,000,000. Therefore, the retrofitting cost is approximately $23.6 \%$ of the cost to build the new house. The average retrofitting cost should be in a range of $15-20 \%$. In this particular case, the wall height is above normal [6].

The material cost of one roll of wire mesh (1-meter $\mathrm{x}$ 23 meter) was IDR 180,000. This house used ten rolls of wire mesh. Therefore, the material cost of wire mesh for this retrofitting house was IDR 1,800,000 (approximately US\$160).

This increase was the result that the construction was used as training, therefore, the cost became a little bit high. The cost should be reduced to $20 \%$.

Table 3. Estimation of additional work (rate Us $\$ 1=\operatorname{Idr} 11,000$ $-2014)$

\begin{tabular}{|l|c|c|c|c|}
\hline & Unit & Volume & $\begin{array}{c}\text { Unit price } \\
\text { (IDR) }\end{array}$ & $\begin{array}{c}\text { Total cost } \\
\text { (IDR) }\end{array}$ \\
\hline Cement water mix & Ls & 1.00 & 200,000 & 200,000 \\
\hline $\begin{array}{l}\text { Installation of wire } \\
\text { mesh }\end{array}$ & $\mathrm{m}^{2}$ & 280.46 & 28,066 & $7,871,501$ \\
\hline $\begin{array}{l}\text { Plastering on brick } \\
\text { walls }\end{array}$ & $\mathrm{m}^{2}$ & 280.46 & 45,966 & $12,981,689$ \\
\hline \multicolumn{4}{|c|}{ Total cost } & $20,963,190$ \\
\hline
\end{tabular}

\section{Conclusion}

Based on the case study, the government should perform longitudinal studies after any reconstruction programs. It is strongly suggested to immediately implement vulnerability reduction in Yogya and start disseminating retrofitting of existing houses using wire mesh as ferrocement layers. It is suggested to introduce the subject non-engineered construction in Universities as well as in the curriculum of technical high schools and also to raise the competence of local tradesmen.

All those who supported this study is gratefully acknowledged.

\section{References}

1. Bappenas, (2006)

2. International Recovery Platform, "The Yogyakarta and Central Java Earthquake 2006 Recovery Status Report," (2009)

3. T. Boen, Constructing Seismic Resistant Masonry Houses, Jakarta: United Nations Center for Regional Development (UNCRD) - Disaster Management Planning Hyogo Office, (2005)

4. T. Boen, Poster Minimum Requirements Building Brick Wall / Earthquake Resistant Brick with Reinforced Concrete Wall Reinforced Ampig Bricks , Jakarta, (2005)
5. T. Boen, Retrofitting Simple Buildings Damaged by Earthquakes, 2nd ed., Hyogo: United Nations Center for Regional Development (UNCRD), (2010)

6. T. Boen, Learning from Earthquake Damage: NonEngineered Construction in Indonesia, Yogyakarta: Gadjah Mada University Press, (2016) 